soyabean meal. The lysine/DE ratio of these diets was $3.6 \mathrm{~g} / 1000 \mathrm{Kcal}$. They were offered ad libitum between 11 and $27 \mathrm{~kg}$ live weight. Each batch of fresh wheat was compared to a batch of wheat stored for one year. The trial was made on 480 Large White piglets weaned at 4 weeks of age.

Freshly harvested wheat - ripe at harvest - did not alter either the appearance, or the health condition, or the piglet behaviour. It led on an average to performance very similar (slightly higher) to those obtained with wheat stored for one year, with nevertheless slight differences in growth and feed intake according to batches.

Accordingly, freshly harvested wheat may be offered without any problem to piglets. It may also be used for bacon pigs which are generally less sensitive than piglets.

\title{
Prediction of the energy value of sorghum on the basis of its tannin content
}

\author{
J.M. PEREZ, D. BOURDON \\ I.N.R.A., Station de Recherches sur l'Elevage des Porcs, \\ Saint-Gilles, 35590 L'Hermitage \\ France
}

Two digestibility experiments were made on 16 and 20 Large White castrated male pigs, respectively, to study the effect of tannins on the energy and protein value of sorghum varieties. The animals with a mean live weight of $36.6 \mathrm{~kg}$ were kept in individual pens, then alloted to groups of 4 or 5 animals and received diets exclusively based on cercals. Total excreta were collected for 10 consecutive days. Six batches of sorghum were tested by comparison with two batches of maize used as controls. The tannin contents of sorghum ranged between 0.21 and 1.57 p. 100 of the dry matter.

A close correlation was found between the energy value (DE) of sorghum varieties and the tannin contents, expressed by the following relation :

$$
\begin{gathered}
\mathrm{DE}(\mathrm{Kcal} / \mathrm{kg} \mathrm{DM})=3908-263 \text { tannins }(\mathrm{p} .100 \mathrm{DM}) \\
(\mathrm{r}=-0.92, \mathrm{P}<0.01, \mathrm{RSD}=1.7 \mathrm{p} .100) .
\end{gathered}
$$

This regression equation allowed a good prediction of the energy value of a batch of sorghum on the basis of a correction of minus $260 \mathrm{Kcal}$ per point of tannins in the grain dry matter.

Sorghum tannins exerted a depressive effect both on the apparent digestibility of energy and nitrogen, i.e. a reduction of the digestibility coefficients of about 6 points per point of tannin :

$$
\begin{aligned}
& \text { aNDC }=70.0-6.17 \text { tannins }(p .100 \mathrm{DM}) \\
& (\mathrm{r}=-0.89, \mathrm{P}<0.01, \mathrm{RSD}=2.7 \text { p. } 100) .
\end{aligned}
$$

\section{Comparison of French sorghum varieties with different tannin contents in bacon pig feeding}

\author{
F. GROSIEAN *, I. CASTAING ** \\ * I.T.C.F., 8, avenue du Président-Wilson, 75116 Paris \\ **A.G.P.M., 122, boulevard Tourasse, 64000 Pau \\ France
}

In a first trial, a maize-soyabean diet was compared with three experimental diets containing either a high, a medium or a low tannin sorghum $(14,10$ and $2 \mathrm{~g}$ tannin, respec- 
tively per $\mathrm{kg} \mathrm{DM}$ ). In addition to the cereal, the four diets contained soyabean meal and a mineral and vitamin mixture. They were offered to 96 animals between 23 and $103 \mathrm{~kg}$ liveweight according to a feed restriction plan.

The feed efficiency of the diet based on maize was similar to that of the diet based on low tannin sorghum. Conversely, it was reduced by 3.1 and 7.9 p. 100, respectively with the other two diets.

In a second trial also made in feed restriction conditions a large number of animals per diet (48) was used to determine the difference between a diet based on maize and a diet based on low tannin sorghum $(2.3 \mathrm{~g} / \mathrm{kg} \mathrm{DM})$. Maize and sorghum were supposed to have the same energy value (3950 Kcal DE/ kg DM). Similar growth performance were observed with both diets thus confirming this hypothesis.

\title{
Use of moist grain maize with cobs in bacon pig feeding
}

\author{
J. CASTAING *, R. COUDURE *, F. GROSJEAN ** \\ *A.G.P.M., 122, boulevard Tourasse, 64000 Pau \\ *: I.T.C.F., 8, avenue du Président-Wilson, 75116 Paris
}

France

Two trials were made to compare the use of different grain maize silages including cobs or not (harvest 1982). Bacon pigs were fed according to a feed restriction plan supplying the same amount of dry matter in each diet. In the first trial, a grain maize silage (37 p. 100 moisture) was compared to two silages including cobs (CCM) ${ }^{*}$ ) and with a moisture content of 41 and 48 p. 100, respectively. Both CCM silages led to similar growth and carcass performance. As compared to the cob free diet, CCM reduced the growth rate and deteriorated the feed conversion ratio by $6.2 \mathrm{p}$. 100 , decreased the carcass yield by 0.5 point and improved the lean percentage by 1.5 point.

In the second trial we compared a grain maize silage to two CCM silages including almost 50 and $90 \mathrm{p} .100$ of the cobs and to a silage of whole ears without husks. The last two silages decreased the growth rate by 4.9 and 7.4 p. 100 as compared to the control diet, but increased the muscle percentage of the carcasses by one point. The carcass yield was the same whatever the diet.

These results were compared to those of three trials made in 1981. As compared to a grain maize silage alone, CCM (with the same moisture content) deteriorated the feed conversion ratio by 0.61 p. 100 on an average per point of cobs in the silage.

\section{Utilization of hydrolysed lactose by the pig}

\author{
C. FEVRIER, D. RANDRIANARIJAONA \\ I.N.R.A., Station de Recherches sur l'Elevage des Porcs, \\ Saint-Gilles, 35590 L'Hermitage \\ France
}

The nutritive value of lactose hydrolysed at the rate of $80 \mathrm{p} .100$ by passage on resins at $90-95^{\circ} \mathrm{C}$ (La Prospérité Fermière) was studied during two experiments. Protein and energy balances were measured in 16 Large White castrated male pigs of about $70 \mathrm{~kg}$

(*) CCM : Corn Cob Mix. 